\title{
The Importance of Music for Alzheimer's Disease Sufferers
}

\author{
Joana Maia \\ University College London - joana.homem.18@ucl.ac.uk
}

\begin{abstract}
The issue of how music may impact Alzheimer's patients, namely by helping regulate emotional instability and being a potential alternative to the usage of verbal language (which is, in most cases, affected in the context of Alzheimer's), has been examined by some researchers, especially within the fields of Psychology, Musicology and Neuroscience. The topic of music as an attenuator of Alzheimer's disease symptoms is yet to be explored to its full extent. This article will focus on the case of a Portuguese 90-year-old Alzheimer's sufferer, Helena. Potential similarities between Alzheimer's disease and autism, such as the patients' usage of music as

a form of communication and self-expression, will be hypothesised, by comparing Helena's case with the one of Romy - a child with autism -, and by alluding to Adam Ockelford's literature in this regard. Helena's reactions to and interactions with music will allow us to understand how music may function as a mood regulator, a way of expressing emotions, and a memory enhancer. In some cases, music is a powerful tool for Alzheimer's patients' families and caregivers, as it helps improve the quality of the interactions they establish with the patients and optimise their insertion and integration in daily life, which Helena's case comes to prove.
\end{abstract}

Keywords: Music, Alzheimer's, elderly, memory, inclusion, integration.

\section{A Importância da Música no Contexto da Doença de Alzheimer}

\section{Sumário}

O impacto da música em doentes de Alzheimer, tanto pelo seu funcionamento como elemento regulador da sua instabilidade emocional, como por constituir uma potencial alternativa ao uso da linguagem verbal (na maioria dos casos, afetada no contexto da doença de Alzheimer) tem sido analisado por vários investigadores, maioritariamente nos campos da Psicologia, Musicologia e Neurociência. A hipótese de a música ser um potencial atenuador da sintomatologia geral caracterizadora do Alzheimer carece, ainda, de investigação científica substancial. Este artigo centrar-se-á no caso de uma doente de Alzheimer de 90 anos: Helena. Hipóteses relativamente a potenciais semelhanças entre a doença de Alzheimer e o autismo, como, por exemplo, o uso da música, por parte dos doentes, como forma de comunicação e de autoexpressão, serão formuladas através da 
comparação do caso de Helena com o de Romy - uma criança autista - e da alusão a literatura de Adam Ockelford relevante para este campo temático. As reações e interações de Helena com a música permitir-nos-ão compreender de que modo a música pode funcionar como um regulador de estado(s) de espírito, como uma forma de expressão emocional e como um elemento estimulador da memória. Em alguns casos, a música é uma ferramenta valiosa para as famílias e cuidadores de doentes de Alzheimer, pelo facto de ajudar a melhorar a qualidade das suas interações e de otimizar a inserção e integração dos doentes em várias atividades da vida quotidiana, tal como o caso de Helena pretende comprovar.

Palavras-Chave: Música, Alzheimer, idosos, memória, inclusão, integração.

\section{INTRODUCTION}

This article is aimed to analyse and discuss the importance of music for Alzheimer's disease sufferers. The whole discussion will be based on empirical data whose collection has been possible due to the kinship relationship between the holder of this piece of research and the protagonist of the case study to be presented. The set of episodes which will be narrated and described throughout this article will, thus, be the result of direct observation, which will always seek to be balanced with and supported by academic literature, specialised on both the field of music and the field of Alzheimer's. This case study will be focused on Helena, a Portuguese 90-year-old who suffers from Alzheimer's and who has always demonstrated to have a very strong connection with music. The narration of Helena's behaviours is intended to analyse and illustrate the important role that music can play in some Alzheimer's sufferers' lives. After providing some contextual information about Helena, a brief comparison between Alzheimer's disease and autism will be established and the importance of music as a means of communication will be clarified. There are studies which hypothesise that similarities between Alzheimer's disease and autism can be established, one of them being Sokol, Maloney, Bay and Lahiris (2011) piece of research. The choice of the above-mentioned comparison is, thus, due to the fact that there is a certain degree of convergence between the two diseases, both in terms of symptoms and behaviour, as Sokol et al., (2011) study suggests. Resemblances between the relationship that Alzheimer's disease patients and the one that autism patients may establish with music will become increasingly evident throughout this article, mainly through 
to Ockelford's (2017) narration of the music lessons he provided to Romy - a child suffering from autism. Such narration will, thereafter, be compared with some behavioural aspects of Helena's case. Afterwards, the topic of music as both a mood regulator and a mode of emotional expression will be explored. Finally, the theme of music as a memory enhancer will be examined. In this context, the case of Ted McDermott, an Alzheimer's disease patient who, even though exhibits some evident features of the disease, is able to recall the lyrics and to accurately sing of several songs which integrated his youth and adulthood. Ted became rather popular in England due to his singing videos, filmed and posted online by his son, and because of the book his son wrote about him - The Songaminute Man (McDermott, 2018). Ted's relationship with and behaviour towards music will be compared with Helena's, and some similarities between the two cases will be established.

\section{HELENA: INTRODUCTORY / CONTEXTUAL INFORMATION}

Helena is a 90-year-old widow who has been suffering from Alzheimer's for almost eight years. Currently, she still lives at her own house and all her needs, namely in terms of personal care, food preparation, general healthcare, mobility assistance and home organisation (c.f. Aging in Place, 2019) are fully attended and assured by a team of four caregivers, who accompany Helena on a permanent basis. Helena was born in Torres Novas (Portugal) and her family was rather conservative. An early manifestation of Helena's interest in music was the fact that, in the context of her youth, she sang in her local church's choir for many years. Helena's dream, however, was to acquire some professional knowledge of music, so as to become a performer subsequently. Nevertheless, and due to the conservativeness that characterised Helena's family, she was never allowed to pursue her aspirations of becoming a singer, as will be described in further detail throughout this article. Even so, Helena continued to sing informally, and music has always been a pivotal part of her daily life. The difficulties Helena experiences with regards to verbal communication are currently evident when observing her. Even though she manages to recognise her relatives, Helena does not have the capacity to recall their names, ages, or degree of kinship. However, she can often sing and follow the melodic line of entire pieces of music, most of them being, somehow, connected to her past, as the following sections are intended to demonstrate. 


\section{MUSIC AS A WAY OF COMMUNICATING: POTENTIAL SIMMILARITIES BETWEEN ALZHEIMER'S DISEASE AND AUTISM}

Adam Ockelford recognises that there are core differences between language and music as means of communication. However, the author also suggests that both are 'uniquely human forms of communication, which appear to have featured in all societies from time immemorial' $(2013$, p. 28). When Ockelford describes autistic children with regards to verbal language, he states that one of their main difficulties is to deal with 'the [...] intricacies of verbal language' (idem, p. 29). This is a clear similarity shared by autism and Alzheimer's. For example, Melissa Brotons and Susan Koger suggest that '[d]ementias, such as Alzheimer's disease, include a progressive deterioration of language functioning' (2000, p. 183). Ockelford (2017) described musical sessions he led with autistic children. One of those is Romy, who seems to have several behavioural similarities with 90 -year-old Helena. When describing his interactions with Romy, Ockelford emphasises the fact that she manages to communicate what she feels and thinks, create humorous scenarios and express sadness through the music that she plays. In conclusion, for Romy, music represents a powerful means of communication or, in other words, a language (Ockelford, 2017). Similarly, Helena's usage of music as a form of self-expression is evident. For instance, when the theme of a given conversation does not please her, she starts whistling or singing, as an attempt to change the subject. Moreover, there are moments (even though they tend to become rarer throughout time) in which Helena is singing whilst staring and smiling at the people around them, almost as if she was establishing a conversation and expressing herself through music. Behaviours of this nature are, to some extent, summarised and clarified in Brotons's and Koger's study: '[...] with regard to $\mathrm{DAT}^{1}$, there are reports of patients continuing to sing old songs despite aphasia and memory loss (Braben, 1992), and of preserved ability to perform musically' (2000, p. 192). Brotons's and Koger's piece of research seems particularly interesting when depicting the topic of music and communication in Alzheimer's patients. The authors, who argue that music can be a 'noninvasive mechanism to enhance communication' (Brotons \& Koger, 2000, p. 184), conducted a study in which elderly participants experienced three months (at least) of music therapy prior to the investigation. This was combined with four conversational sessions and four music sessions. The following

1 Dementia of the Alzheimer's Type. 
graph compares participants' performance, in terms of content and fluency, during conversational and musical sessions:

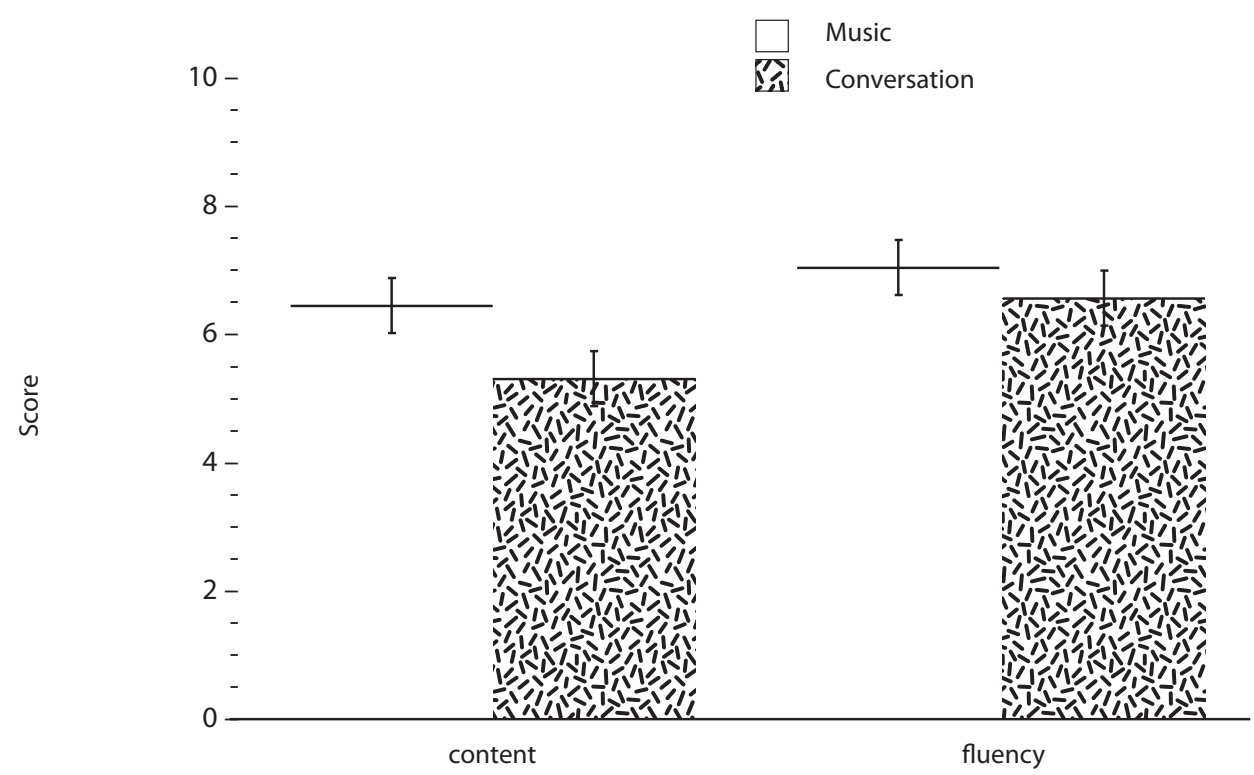

Figure 1. 'Overall performance on content and fluency in music versus conversation conditions' (Brotons \& Koger, 2000, p. 189)

The graph presented above shows that participants' performance in music on both the domains analysed (content and fluency) was better in music than in conversational sessions. The authors suggest that 'music therapy interventions may positively influence [...] speech [...] in people affected by DAT' (p. 192), and the cases of Romy (in a specialised way) and Helena (who experiences an informal family-led approach) seem to be in accordance with Brotons's and Koger's suggestions.

\section{MUSIC AS A MOOD REGULATOR AND AS AN EXPRESSION OF EMOTIONS}

\subsection{Mood regulation through music}

As a person with Alzheimer's, Helena has been demonstrating, throughout the 
years, increasing signs of the 'irritability, apathy [and] lethargy' mentioned by Warran and Welch (2019, p. 43) when describing some of the most common symptoms experienced by people suffering from dementia. Also, as stated by Alzheimer's Society (2018), sufferers from this illness 'will often have changes in their mood' and 'may become anxious, irritable or depressed'. These mood changes can sometimes happen suddenly and unexpectedly. Helena's family classified the days when they would find her more irritable and emotionally unstable as bad mood days. Helena's daughter has recently found a mechanism which tends to relax Helena and to distract her from negativity: she starts playing Doris Day's Que Sera Sera, or Carlos Mendes's Amélia dos Olhos Doces (which is part of the repertoire of Portuguese folk music from the 70s) on YouTube. Helena's typical reaction to this is instinctively starting to sing along and, by doing that, her mood automatically improves, as the song seems to distract her from anxiety and irritability. It is important to clarify that the abovementioned songs were some of the ones that Helena used to sing more frequently in past times. Another episode that illustrates how music can function as an anxiety and instability regulator is related to the passing of Helena's husband, in December 2018. Due to Helena's age and physical and emotional fragility, her family decided not to inform her about the situation. At this stage, Helena's unconsciousness about her husband's absences (which were constant, as, prior to his death, he had to leave their house three times a week, at least, to do hemodialysis, and also because, in the last four years, he had been hospitalised several times) was increasing. Even though Helena was being maintained stable by not being made aware of her husband's passing, two weeks after this happened, she experienced a rather unstable day, in which she said to her caregiver that the house she was in was not hers (maybe because the usual noises that her husband's treatments at home involved were no longer occurring) and that she wanted to go to her house with her husband. She also asked the caregiver why, lately, her husband was always sleeping. This situation worried Helena's family and, on the day after she showed these signs of anxiety, her daughter went to her house and found her calmer. While having lunch together, Helena's daughter played Que Sera Sera once again, on YouTube, but she was not quite sure whether Helena would sing along as she used to. Nevertheless, she did sing along and her mood (characterised by some apathy) significantly improved. In the future, music may, therefore, be one of the main mechanisms which could help Helena deal with her husband's absence. Scenarios such as the ones described above confirm Brotons's and Koger's suggestions regarding the positive emotional effects and the 'palliative role' (2000, p. 
192) of music in people suffering from Alzheimer's, as 'music taps into more "primitive" anatomical structures such as those involved in emotional experience' (ibid.).

\subsection{Music / Sound as a form of emotional expression}

Since her illness started developing, and apart from being a mood regulator, music (and sound in general) has been acquiring other vital functions for Helena, in what concerns as emotional expression. This is particularly visible when she is experiencing higher degrees of anxiety. To illustrate behaviours of this nature, an episode which happened in September 2017 will be described. Helena's husband suffered from chronic kidney disease and needed to be hospitalised for about a month. It is important to note that, by 2017 , Helena still had the capacity to entirely notice her husband's absence from their house. With regards to Alzheimer's, Joanne Coste states that 'the emotion behind failing words is far more important than the words themselves and needs to be validated.' (2003, p. 7). The author, then, adds: '[a]lthough many losses occur with this disease, [...] the patient can still register feelings that matter.' (ibid.). In fact, people with Alzheimer's become progressively unable to express themselves through sentences (or even single words). In the case of Helena, her speech, which by 2017 was not as affected as it is nowadays, severely declined due to the extreme levels of anxiety that the absence of her husband had caused. Helena's family, as well as her caregivers, made several attempts in order to lead her to express her feelings. However, Helena's anxiety escalated to a level in which she would only communicate by uninterruptedly repeating the sounds $b a$ $b a b a$ (which almost resembled the sounds produced by babies). The repetitiveness of these sounds was frequently accompanied by repetitive hand gestures. The $b a b a$ ba sounds were the clearest expression of Helena's emotional instability and were the most accurate means she found to exteriorise her emotional state. One could argue that Helena's speech had simply worsened as a natural consequence of her illness. Nevertheless, when her husband was discharged from hospital and returned home, her speech progressively started to improve. Therefore, for Helena, sound represented a way of coping and exteriorising her emotions while her husband was hospitalised. The idea that music can be a way of dealing with anxiety (cf. El Haj, Fasotti, \& Allain, 2012) and other potentially negative symptoms connected to Alzheimer's, and a form of emotional expression, is supported by the Alzheimer Society of Canada (2019): 'when words fail, music provides a way for the person with dementia to (...) engage with memories and emotions'. The Alzheimer society 
of Canada also suggests that music can have a 'profound effect (...) on quality of life for everyone affected by dementia'.

\section{CAN PAST LIFE CONTEXTS INFLUENCE ALZHEIMER'S PATIENTS' REACTION TO MUSIC? MUSIC AND MEMORY - A COMPARISON BETWEEN THE SONGAMINUTE MAN AND HELENA}

\subsection{Biographical / professional contexts and the desire to restore the past}

The first comparative factor between Ted McDermott and Helena that deserves to be highlighted is the connection they have had to music throughout their lives. Simon McDermott (2018) describes his father as someone whose life purposes were never driven by a desire for wealth or material goods. Instead, the idea of happiness Ted cherished the most was connected to pleasing his loved ones through entertainment. Ted always had a strong relationship with his family and looking after them and providing for them was, for him, a mission and gave him a sense of purpose (McDermott, 2018). As a teenager, Ted began to work in a factory, but soon engaged in the music realm and became a singer in pubs and clubs, locally and abroad, where he mostly sang classics from the 1960s and 1970s (Haworth \& Kitching, 2016). The description McDermott makes of his father can entirely be resembled to Helena's case. Her enjoyment for entertaining others can be observed, for instance, through photographs taken during her youth, in which she would often be dressed in theatre costumes. Helena has always been described by her sons and daughters as an extremely creative person, who would create rhymes and poems of her own in a matter of a few minutes, and who would perform the most hilarious and accurate imitations of people from her daily life. Since Helena was young, her dream had always been to be a singer and an actress. However, her family was extremely conservative and entirely based on patriarchal ideals. Helena was the second eldest child out of seven children, and her father never thought that a career as a performer would suit her, as he considered that staying home to look after her younger siblings was her true obligation. Being part of a family which embraced such conservative values, the only musical activity Helena was allowed to do was singing in the local church choir. Nevertheless, and even though Helena did not have the opportunity to become a professional singer, she continued singing informally throughout her life. McDermott (2018) accurately describes a trait shared by many Alzheimer's patients - their 'obsession' over 
the past - and illustrates it by narrating an episode in which his father refused to let go of objects which were part of his household in the past, but stopped working throughout time. McDermott states that, when he became aware of this scenario (there was an immensity of objects of this nature, stored in the family's back garden), he tried to convince his father to let go of, at least, some of those items. However, Ted's response was characterised by a high level of hostility and verbal aggressiveness. Helena's 'obsessions' over past times are also connected to physical objects. For instance, she often asks her daughter or caregiver to see her jewellery and is frequently afraid someone may steal it from her. Nevertheless, the 'obsessions' Helena evidences the most are the ones related to daily-life activities, especially household shores. Helena was a housewife throughout her whole life, and obviously became highly familiar with practices such as dusting, doing laundry, among many others. Nowadays, even though Helena is unable to perform any of those activities, she mimics some gestures connected to them. When, for example, she finds an unfolded towel on the kitchen table, she instinctively grabs it and starts folding it. When her family praises her for this sort of practice, Helena seems to show some contentment and to feel proud of herself, probably because, to an extent, she feels that a part of her life as it was in past times is momentarily being restored. McDermott's description of Ted's behaviour in the episode mentioned above may not seem comparable to Helena's, as, on one hand, Ted's reaction happened momentarily - McDermott states that, half an hour after the argument with his father occurred, Ted had forgotten what had happened and offered to help his son freeing the garden from the old objects - and, on the other hand, Helena's behaviours seem to have become a daily pattern already. However, both Ted and Helena seem to reveal a major need to have references from their past, as they seem to provide them with a sense of safety, comfort and stability.

\subsection{Music and memory: music as a reference to the past}

The previous section of this research aimed, on one hand, to describe Ted's and Helena's close relationship with music and, on the other hand, to illustrate the urges they often demonstrate to recover their past routines. This section intends to analyse some of Ted's and Helena's reactions to and interactions with music, and to connect them with the previous section of this article, by suggesting that Alzheimer's patients' biographical backgrounds can influence their behaviour with regards to music. That does not necessarily mean that the Alzheimer's disease sufferers whose past was deeply connected to music are the only ones presenting behavioural changes when 
contacting with music. The documentary Alive Inside (Rossato-Bennett \& McDougald, 2014) shows how music can be a powerful (sometimes, even decisive) tool for people suffering from Alzheimer's and other types of dementia. That is most likely due to the fact that even if one does not build a clear, deep relationship with music throughout one's life, one is permanently surrounded by music (or, at least, sound), which is why Rentfrow (2012) argues that 'music is ubiquitous' (p. 402). The fact that music is an inevitable part of people's lives may explain why it tends to work as a memory trigger for Alzheimer's sufferers. Moreover, music often works as a brain stimulator (Jäncke, 2008; Baird \& Samson, 2009; Rossato-Bennett \& McDougald, 2014), which is, per se, a reason that may explain some dementia sufferers' positive reactions to music. This section, however, is mainly intended to show how Ted and Helena's current behaviours with regards to music are particularly connected to their biographical background.

In Ted's case, and according to his son, the more Ted's disease progressed, the more aggressive he would become. Ted's son soon realised that one of the best ways to deal with his father's increasing aggressiveness and memory loss was taking him to his car and playing some music for them to sing along. Simon McDermott started filming his father's 'car performances' and posted them on YouTube. The most famous video that features Ted and Simon in the car is the one in which they are singing Engelbert Humperdinck's Quando Quando Quando, a song from 1962. This information (the one concerning the year when the song was recorded) is, to some extent, important for this discussion, because, as mentioned in the last section, during Ted's youth and adulthood, he sang professionally in pubs and clubs, and the main songs that his repertoire included were classics from the 1960s and 1970s. The YouTube video was uploaded in 2016. Ted was 79 then, and, as described in The Songaminute Man (2018), he had reached a stage in which he often could not recognise his closest relatives. Nevertheless, when singing Humperdinck's song, Ted could recall every word from its lyrics and its entire melodic line. He sang the song, alongside his son, from its beginning to its ending. Simon's initiative to lead his father through this sort of 'carpool karaokes', which clearly included songs Ted may have performed in the past, might be an unconscious application of the concept of 'music-evoked autobiographical memories' (El Haj et al., 2012, p. 238). The fact that Ted's Alzheimer's symptoms, especially in terms of behaviour and memory, improve significantly when he is singing songs he knows by heart suggests that one of the first hypothesis formulated in El Haj et al's article is probably accurate: 'music-enhanced autobiographical recall was suggested to be related to [...] 


\section{The Importance of Music for Alzheimer's Disease Sufferers}

arousal improvement (Foster \& Valentine, 2001), anxiety reduction (Irish et al., 2006), and emotional enhancement' (El Haj et al., 2012, p. 239). A more recent study which hypothesises that some Alzheimer's disease patients' past memories can be triggered by music, namely in music therapy sessions, was conducted by Mathews (2015), who refers to Henry (a patient suffering from dementia), to illustrate and validate his hypothesis. As the author describes, after playing a song familiar to Henry,

'his recognition of the music associates with the recognition of himself as he was when he first heard it (...). There are significant gaps in Henry's autobiographical memory system, but what matters is that he can connect to a past that is his own, and so he gets back part of the narrative selfhood that is central to his self-understanding.' (p. 578)

To an extent, even though there are inevitable differences between Henry (who is followed by a music therapy specialist) and Helena and Ted (whose contact with music seems to happen in more informal settings), there also is a fundamental similarity amongst these three dementia sufferers, which is the power that music has to evoke past, autobiographical memories. Helena's case presents some similarities with Ted's, even though the manifestations of her disease's symptoms are less connected with aggressiveness and more related to memory loss and communication difficulty. When Helena's daughter or grandchildren play songs she knows on YouTube, they become her immediate focus of attention. Even though Helena cannot recall any song's exact lyrics, she still recognises some songs' entire melodic lines instinctively, and often starts singing along once a song is being played. Helena's family frequently plays music to her that was part of her adulthood (Portuguese artists such as Carlos Mendes, Paulo de Carvalho, Simone de Oliveira, and foreign artists such as Doris Day) and that seems to be the most effective way of communicating with her and to exercise her musical and, to some extent, her biographical memory. There was, for example, an episode in which Helena's daughter was playing the song Os Meninos de Huambo, by Paulo de Carvalho (another song included in the Portuguese folk music repertoire - this time from the 80s) on YouTube, and Helena voluntary made a comment which left all the family positively surprised. She said, 'we used to have Paulo de Carvalho's vinyl'. Helena's daughter confirmed that that was true. On another occasion that happened on the same day, I played to her Desfolhada, a song originally performed by Simone de Oliveira in the Eurovision Song Contest of 1969. Simone de Oliveira was 
(and still is) considered a symbol of Portuguese musical culture. Nevertheless, at a certain point of her career, she had health issues that severely damaged her vocal folds. When Helena was listening to Desfolhada on YouTube, on that day, she made a surprisingly accurate comment about the singer. Referring to the video, she said 'her voice was still so beautiful and normal back then'. Helena's use of the word still was extremely important, as it obligatory implicated she had a notion of the difference between Simone de Oliveira's voice before and after her health condition arose. Moreover, the fact that Helena's memory allowed her to remember that Simone de Oliveira had a vocal health issue itself seems positively unusual. It seems vital to reinforce that the fact that Helena could recall those pieces of information, concerning both Paulo de Carvalho and Simone de Oliveira, was made possible simply by listening to their music. El Haj et al. (2012) suggest that 'the power of music as a memory enhancer should be more often considered when assessing memory performance of $\mathrm{AD}^{2}$ patients' (p. 45). Alzheimer's is a disease which, once acquired, tends to worsen throughout time. Nevertheless, nowadays, and apart from medication, music seems to be the one of the most effective ways to prevent Alzheimer's symptoms from quickly and suddenly escalating and has a pivotal role regarding the attenuation of such symptoms (at least in what concerns to Helena's case). To some extent, music is contributing to maintain Helena in a stage which is still characterised by a certain degree of stability and simultaneously decelerating an abrupt and/or total memory loss.

\section{CONCLUSION}

It is unquestionable that music is pivotal for Helena, and its positive effects in her current daily life, especially in terms of communication and emotional expression, mood regulation and memory enhancement, are easily verifiable through the example episodes narrated and analysed throughout this article. In the context the topic of music as a form of communication, some key-behaviours of Helena (an Alzheimer's disease patient) towards music were compared to the ones exhibited by Romy (a child suffering from autism). That allowed us to hypothesise and establish some general behavioural similarities between Alzheimer's disease and autism, which are, to an extent, corroborated by literature relevant for this analysis. This article also allowed us to examine, through the depiction of Helena's case, and with particular emphasis on

2 Alzheimer's disease. 


\section{The Importance of Music for Alzheimer's Disease Sufferers}

the episodes connected to her husband, how music and sound can help Alzheimer's sufferers express their emotions, when the resort to verbal language is no longer a tangible option. Finally, this piece of research was intended to show how, in Helena's case, her current relationship with music and its positive effects regarding her disease may be intrinsically connected to the strong presence of music throughout her youth and adulthood. In this context, a comparison between her case and Ted McDermott's (who also suffers from Alzheimer's and who has always had a deep connection with music as well) was established, in order to examine how music can foster and enhance Alzheimer's disease patients' memory. That happened to both Helena and Ted, who clearly found in music a reference to some of their past experiences.

It is, however, also important to note that Helena's positive reactions to music do not allow us to state that music can function as an 'adjunct therapy' (as it does in her case) for all Alzheimer's patients, as each of them has their own behavioural specificities and will, therefore, have different reactions to different stimuli. Nevertheless, as mentioned by Sunderland et al. (2018), 'arts can have a significant role in promoting mental and physical health and general well-being of older people' (p. 142) and music is, undoubtedly, powerful for brain stimulation (Jäncke, 2008; Baird \& Samson, 2009; Rossato-Bennett \& McDougald, 2014). Thus, it always seems worth attempting to introduce (or reintroduce) music in Alzheimer's patients' lives, as music is inevitably an integral part of one's daily life - as stated by Rentfrow (2012), 'music is ubiquitous' (p. 402) - and, therefore, it is possible that patients will regain a stronger connection with their relatives and carers and a deeper notion of the world around them through their contact with music. In an attempt to answer to the question raised by Warran and Welch $(2019$, p. 44$)$, with regards to what seems to be the best type of music to use when interacting with Alzheimer's disease sufferers, in Helena's specific case, the type of music that seems to captivate her most is Portuguese folk music. However, this is probably not due to the intrinsic features of this type of music, but, instead, to the connection Helena had, in past times, with certain songs that compose Portuguese folk music repertoire. In fact, the songs Helena can sing more accurately are the ones she used to sing in the past. These are also the songs that stimulate her memory the most, and that, simultaneously, contribute to a more effective regulation of her mood swings. Therefore, taking into consideration this article's case study, the idea that music which was a key-part of Alzheimer's patients' lives in past times can be particularly useful when establishing a relationship and interacting with them now seems increasingly pertinent. 


\section{REFERENCES}

Aging in Place. (2019). Caregiver Responsibilities List: Caring for my Parents. Retrieved December 9, 2019, from https://www.aginginplace.org/caregiver-responsibilities-list-caring-for-my-parents/

Alzheimer's Society. (2018). Symptoms of Alzheimer's disease. Retrieved September 15, 2019 from https://www.alzheimers.org.uk/about-dementia/types-dementia/ alzheimers-diseasesymptoms\#content-start

Alzheimer Society of Canada. (2019). The power of music. Retrieved December 10, 2019 from https://alzheimer.ca/en/Home/We-can-help/Resources/Power-ofmusic

Baird, A., \& Samson, S. (2009). Memory for Music in Alzheimer's Disease: Unforgettable? Neuropsychology Review, 9(1), 85-101.

Brotons, M., \& Koger, S. (2000). The Impact of Music Therapy on Language Functioning in Dementia. Journal of Music Therapy, 37(3), 183-195.

Coste, J. K. (2003). Learning to Speak Alzheimer's: A Groundbreaking Approach for Everyone Dealing with the Disease. USA: Houghton Mifflin Harcourt.

El Haj, M., Fasotti, L., \& Allain, P. (2012). The involuntary nature of music-evoked autobiographical memories in Alzheimer's disease. Consciousness and Cognition, 21 (1), 238-46.

Haworth, J., \& Kitching, C. (2016, November 23). Son who films dad with Alzheimers singing in car in heartbreaking videos raises $£ 130,000$ for charity. The Mirror. Retrieved September 3, 2019 from https://www.mirror.co.uk/news/uk-news/ son-who-films-dad-alzheimers-9319674

Jäncke, L. (2008). Music, memory and emotion. Journal of Biology, 21. https://doi. org/10.1186/jbiol82

Mathews, S. (2015). Dementia and the Power of Music Therapy'Bioethics, 29 (8), 573-579.

McDermott, S. (2018). The Songaminute Man. United Kingdom: HarperCollins. 


\section{The Importance of Music for Alzheimer's Disease Sufferers}

Ockelford, A. (2017). Comparing Notes: How We Make Sense of Music. United Kingdom: Profile Books.

Ockelford, A. (2013). Music, Language and Autism: Exceptional Strategies for Exceptional Minds. United Kingdom: Jessica Kingsley Publishers.

Rentfrow, P. J. (2012). The Role of Music in Everyday Life: Current Directions in the Social Psychology of Music. Social and Personality Psychology Compass, 6(5), 402-416.

Rossato-Benett, M. (Producer and Director), \& McDougald, A. (Producer). (2014). Alive Inside [Motion Picture]. New York, United States of America.

Sokol, D. K., Maloney, B., Long, J. M., Ray, B., \& Lahiri, D. K. (2011). Autism, Alzheimer disease, and fragile X: APP, FMRP, and mGluR5 are molecular links. Neurology, 76(15), 1344-1352. https://doi.org/10.1212/WNL.0b013e3182166dc7

Sunderland, N., Lewandowski, N., Bendrups, D., \& Bartleet, B.-L. (Eds.) (2018). Music, Health and Wellbeing: Exploring Music for Health Equity and Social Justice. United Kingdom: Palgrave Macmillan.

Warran, K., \& Welch, G. F. (2019) The benefits of instrumental and orchestral music for older people: a call for further research. In From Bingo to Bartok: Creative and Innovative Approaches to Involving Older People with Orchestras (pp. 40-46). London: The Baring Foundation. 